Ann. Biol. anim. Bioch. Biophys., I976, 16 (3), 279-289.

\title{
DEVELOPMENT AND MATURATION OF THE HYPOTHALAMO-HYPOPHYSEAL CONTROL OF THE REPRODUCTIVE SYSTEM
}

\author{
S. M. McCANN \\ Department of Physiology, \\ The University of Texas Health Science Center at Dallas, \\ Southwestern Medical School, \\ Dallas, Texas 75235
}

\section{SUMMARY}

A wealth of new data is now available on the developmental patterns of gonadal steroids, gonadotropins and responsiveness to LH-RH in rat and primate. The process is much more complicated than previously envisioned. It appears that the gonadotropin-releasing mechanism matures at a very early stage. This is followed by high plasma titers of gonadotropins caused, at least in part, by limited development of the negative feedback of gonadal steroids. In the female rat, the high gonadotropin titers induce high titers of estradiol. Following this stage, gonadotropin and steroid titers decline. Around the time of puberty, increased gonadotropin secretion occurs, at least in man, and puberty may be due in part to decreasing responsiveness to negative feedback of gonadal steroids in both sexes, to positive feedback of gonadal steroids in females, and to increased responsiveness of gonads and peripheral tissues to hormonal drive.

\section{INTRODUCTION}

The development of specific radioimmunoassays for pituitary hormones and, more recently, for steroid hormones and even for releasing hormones, has led to a dramatic increase in our knowledge of the developmental changes in these hormones. In this brief review, we will attempt to describe and to compare these changes in two mammalian species, the rat and man. We will then attempt to develop concepts as to the mechanisms involved in the induction of puberty and will point out some of the gaps in our knowledge. 


\section{Developmental changes of hypothalamic, pituitary and gonadal hormones in the rat}

We will first present the known information concerning the levels of these hormones in plasma and sometimes also in their tissue of origin and then develop a concept for the mechanism of onset of puberty in the rat.

\section{Plasma levels of gonadal steroids}

In the male rat, plasma testosterone titers are low shortly after birth, increase thereafter reaching peak values at around days $15-20$, decline during the 4 th week of life and rise gradually afterwards to reach adult levels at about the time of puberty (RESko et al., I968; MrYACHr et al., I973). These data confirmed earlier inferences (PFEIFFER, I936) that the infantile male gonad can produce androgens.

On the other hand, it has been assumed since the early work of PRICE and ORTIZ (I944) that the ovaries produce little or no steroids in the neonatal period. Recently, it has been possible to measure plasma estradiol (MEIJs-Roesofs et $a l$., I973 $b$; WEISz and Gunsalus, I973 ; OJEDA et al., I975) and, more recently, progesterone (MEIJS-RokLoFs et al., I975; DöHLER and WUTTKE, 1974) by radioimmunoassay. The results indicate that plasma estradiol is low up to five days and then increases sharply to reach a peak at ro-I5 days. The peak values are greater than the values obtained at any time during the estrous cycle of the

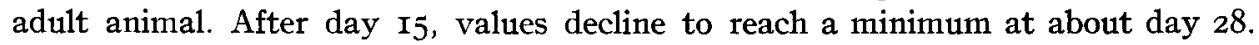
Plasma progesterone, in contrast, begins to rise after day Io and reaches a peak at day 22. It then declines to intermediate levels through day 35 .

\section{Plasma and pituitary levels of gonadotropins and prolactin}

In view of the very surprising early elevations of estrogen and progesterone in the infantile rat, knowledge of the plasma titers of gonadotropins becomes of extreme interest. In the male, there is no doubt that both gonadotropins are present in plasma at an early age as measured by radioimmunoassay. Values for both FSH and LH in neonatal males are relatively elevated and decline to a minimum from day $\mathrm{I} 2$ to I5 (Goldman et al., I97 ; OJEDA and RAMIREz, I972; MrYACHI et al., I973). FSH titers rise to a peak at about day 30 , just prior to the onset of spermatogenesis and then decline to values similar to those seen in the adult (SWERdLoFF et al., I97I ; NEGRO-VILAR et al., I973 $a, b$ ). The association of the decline in plasma FSH with the onset of spermatogenesis suggests that a product originating from the testes, perhaps the fabled inhibin, may inhibit FSH secretion at this time. LH titers in the male are relatively low by comparison with FSH and rise gradually to achieve adult values at about 70 days (McCANN et al., I974). It is tempting to relate the development of the testes which occurs as the animal approaches puberty with the prior elevation in plasma FSH.

Plasma prolactin has been reported to be very low in the infantile male, but to be slightly increased by day 25 with a secondary increase at day 70 (NEGROVILAR et al., I973a); however, in later studies, this increase was not observed unless 
the animals were subjected to ether stress, findings that suggest that minimal stress associated with the blood collection may have produced the developmental elevations in serum prolactin previously reported (OJEDA, JAMESON and MCCANN, unpublished data). Nonetheless, it is possible that the developmental increase in resting or in stress-induced prolactin levels may in fact play a role in testicular and accessory organ growth since available evidence clearly indicates that endogenous prolactin synergizes with gonadal steroids in maintaining the function and structure of the accessory sex organs.

The developmental pattern of FSH release in the female differs from that in the male since plasma FSH rises from already elevated levels at 5 days to a peak at I5 days, and then declines to minimal levels by day 30 , shortly before puberty (KRAGT and DAHLGREN, I972 ; OJEDA and RAMIREZ, I972 ; MCCANy et al., I974; OJEDA, Wheaton, Jameson and McCann, unpublished data).

The pre-pubertal pattern of plasma LH is quite similar for both male and female in that the initial high levels begin to decline at approximately I $_{5}$ days to minimal values and remain low until the time of puberty (OJEDA and RAMIREZ, I972; MEIJS-ROELOFS et al., I973a; OJEDA et al., I975). Recently, DöHLER and WUTTKE (r974), removing blood samples in the afternoon during development instead of earlier in the day as in the aforementioned studies, found remarkable elevations of $\mathrm{LH}$ in certain females even as early as day 2 and extending particularly to day I9, observations that have been recently confirmed in our laboratory (OJEDA, I976). It may be possible that these surges of LH taking place in the afternoons during the infantile period play an important role in the development of the ovary. At any rate, it appears that in the female rat, the gonads fully develop only after they have been exposed to relatively high titers of gonadotropins in the very early days of life.

Prolactin is low during development in the female rat (VoogT et al., I970; OJEDA and MCCANN, I974), but afternoon elevations appear shortly before vaginal opening and are maximal on the first proestrous day, at the time of the preovulatory gonadotropin surge (OJEDA, WHEATON, JAMESON and MCCANN, unpublished data).

As a very brief oversimplification, it can be stated that pituitary content of gonadotropins and prolactin in general parallels the plasma values which have been reported, although the very early neonatal period has not been adequately studied (McCANN et al., I974; MEIJS-ROELOFS, I973).

\section{Response of gonadotropins to castration}

To determine if negative feedback mechanisms are operative during development, two types of experiments have been performed. The first was to examine the response of plasma gonadotropins to removal of the gonads, and the second was to evaluate the response to replacement therapy with gonadal steroids. Castration is followed by elevated levels of plasma gonadotropins at very early ages in both sexes (Goldman et al., I97I ; OJEDA and RAMIREZ, I972 ; MEIJS-RoELOFs et al., $\mathrm{I} 973 \mathrm{~b}$ ) ; however, the response to ovariectomy in the infantile period is much less pronounced than that in the later phases of sexual development.

Conversely, treatment with gonadal steroids, testosterone in the male and to a lesser extent estradiol in the female, can lower plasma gonadotropins in males 
or females, respectively, beginning at a very early age (GoldmaN et al., I97I ; OJEDA and Ramirez, I973; MeIJS-RoELofs et al., I973 b). In the case of the male, old observations obtained by bioassay (RAMIREZ and MCCANN, I965) have been confirmed by radioimmunoassay (NEGRo-ViLAR et al., I973 $b$; BLOCH et al., 1974). The dose of testosterone expressed on a body weight basis required to lower plasma gonadotropin titers in castrates is minimal at earlier ages and rises to a maximum value after puberty. The failure of ODELL and SwERDIOFF (I974) to observe this change in sensitivity with development is probably related to the fact that they delayed the beginning of replacement therapy by five days (NEGRO-VILAR et al., I973 b).

In the female, responsiveness to negative feedback of estrogen is present at an early age, but the responsiveness is less evident than that observed after the third week of life (OJEDA and RAMrREZ, I973; OJEDA et al., I975). Whether there is a decrease in responsiveness around the time of puberty as postulated on the basis of earlier studies (DONOVAN and VAN DER WERFF TEN BOSCH, I965; RAMIREZ and MCCANN, I963 ; SMith and Davidson, I968) remains to be determined. The problem is that no studies have been done around the time of puberty in which replacement therapy has been carried out and the effects on the blood levels of estradiol have been determined. The rate of metabolism of estradiol increases with development (de HerTOGH et al., I970; OJEDA et al., I975) and this could account for the apparent increase in threshold for negative feedback around the time of puberty. At least in the rat there has been no detectable increase in FSH and LH in the immediate pre-pubertal period. If there was a declining sensitivity to negative feedback, one would expect plasma gonadotropins to rise as a result of this, and this would then drive the ovary to produce more steroids, follicular development would take place, and this would be followed by puberty.

\section{Positive feedback of gonadal steroids on gonadotropin release during development}

Early studies with PMS-induced ovulation suggested that the stimulatory feedback of gonadal steroids was operative around day $2 \mathrm{I}$ in the female rat (see Meijs-Roflofs, I973, for references). Caligaris et al., (I972) followed the development of the positive feedback to administered estradiol during development in female rats and observed that the feedback was first present around day $2 \mathrm{I}$ and then increased to a maximum long before the onset of puberty. Very recently, GeIATO and WuTtKe (I975) lowered plasma LH but not FSH in I5 day old rats with injections of anti-estradiol antiserum. This they interpreted as evidence that a positive feedback mechanism was acting on $\mathrm{LH}$ but not FSH even at this very early stage in life. Since this does not agree with what has previously been found, further work is necessary to substantiate this evidence for the very early presence of a positive feedback mechanism.

\section{Peripubertal changes in gonadotropins}

There is no obvious peripubertal change in gonadotropin release in the male rat, but in the female rat, it is clear that a preovulatory discharge of gonadotropins and prolactin takes place on the afternoon prior to the first ovulation (OJEDA, 
WheAton, JAMESon and McCANN, unpublished data). This discharge is similar to that seen in the adult except that the release of FSH is greater than that observed in adult animals.

\section{Developmental changes in gonadotropin-releasing factors}

Hypothalamic LH-RH is present at a very early stage in development (CAMPBEl, and Gallardo, I966). There have been no reported studies of the complete developmental pattern of hypothalamic LH-RH using radioimmunoassay for the decapeptide, but bioassay studies leave little doubt that it is present throughout this period (see McCANN et al., I974). Just at the time of puberty, declines in FSH-RF and LH-RH levels have been reported in the female rat by bioassay (RAMIREz and SAWYer, I966; Corbin and DaNiels, I967; Watanabe and McCANN, I969; KRAGT and DAHLGREN, I972). Recently, we have observed a small decrease in hypothalamic content of immunoassayable LH-RH on the morning following the first ovulation in pubertal females (unpublished observations). All of these studies suggest that the preovulatory discharge of gonadotropins which occurs on the afternoon prior to the first ovulation in the pubertal female rat is brought about by an enhanced release of either FSH-RF and $\mathrm{LH}-\mathrm{RH}$ or a single gonadotropin-releasing hormone. So far, an increase in circulating LH-RH has not been detected at this time (OJEDA, I976). Presumably, the titer in the peripheral circulation is very low even though increased amounts of $\mathrm{LH}-\mathrm{RH}$ are released into the hypophysial portal vessels.

\section{Developmental changes in responses of target glands to trophic hormones}

\section{a) The response of the gonads to gonadotropins.}

This subject has been adequately reviewed recently by MEIJS-ROEIOFS (I973) for the ovary. Suffice it to say here, that there is an early period during which the ovaries do not respond to gonadotropins with ovulation, but that by day $2 \mathrm{r}$ they are capable of ovulation following sufficient gonadotropin stimulation. The detailed changes during ovarian development are described in the earlier paper by Dr PETERS (this volume, Chapter $\mathrm{I}$ ). The fact that puberty does not develop in the female rat for an additional two weeks after ovulation can be induced by gonadotropins suggests that the ovary is not the primary site of the changes which bring about puberty.

In the male, there appears to be an increased responsiveness of the testes to IH brought about by FSH-priming during the early days of life (ODELL and SwERFLOFF, I974). These authors postulate that this is an important factor in the induction of puberty in the male. The increased testicular responsiveness to $\mathrm{LH}$, together with the decreasing sensitivity of the gonadal steroid negative feedback, may bring about pubertal changes in the male.

\section{b) Responsiveness of target tissue to gonadal steroids.}

In addition to the developmental changes in responsiveness of the gonads to gonadotropins, it appears that the responsiveness of peripheral target tissue, such as the uterus and male sex accessories, increases near the time of puberty. 
This was originally shown for the male sex accessories by HOOKER in I 942 and was recently confirmed by OJEDA and RAMIREZ (I973). In the female, uterine growth in response to estradiol reaches a maximum at the time of puberty as well (OJEDA and RAMIREZ, I973; RAMIREZ, I974).

\section{c) Response of the pituitary to $L H-R H$.}

Synthetic LH-RH induces $\mathrm{LH}$ release in newborn rats of both sexes (RooT et al., 1975). In the male rat, purified or synthetic LH-RH released LH at all ages studied beginning at 8 days (MrYACH et al., I973; DEBELJUK et al., I972 a) and the maximal response was observed between days 35 and 45 (DEBELJUK et al., I972 a). Additional work is needed in which the responses to more than one dose are correlated with the maturational status of the animals.

In the case of the female, DEBELJUK et al., (I972 b) observed maximal responsiveness to synthetic $\mathrm{LH}-\mathrm{RH}$ at day $\mathrm{I}_{5}$ with a decline to minimal values at day 35 , around the time of puberty. Responsiveness then increased to a constant level between 45 and 2 ro days. A more thorough, multi-dose study has recently confirmed the early increased responsiveness to LH-RH in females at the time that plasma gonadotropin values are elevated and has shown that the responsiveness is particularly increased with respect to FSH release (OJEDA, 1976). Responsiveness then declines in parallel with the declining gonadotropin titers but is augmented at the time of the first pre-ovulatory gonadotropin discharge. At that time, the priming effect of $\mathrm{L}_{\mathrm{H}} \mathrm{H}-\mathrm{RH}$ which is seen at the time of the pre-ovulatory discharge of gonadotropins in adults (AIYER et al., I974; Castro-VazQuEz and McCANN, I975) is also apparent (OJEDA, I976). The increased responsiveness just prior to the pre-ovulatory discharge may be brought about by ovarian estrogens, as seems dikely in the adult. The priming action of $\mathrm{I}_{1} \mathrm{H}-\mathrm{RH}$ first observed around the time of proestrus in pubertal animals as well as in adults may also be induced by endogenous estrogen (CASTRO-VAzQUEZ and MCCANN, I975) and may play a physiological role in magnifying the preovulatory discharge of gonadotropins.

\section{Current hypotheses to explain the developmental pattern of gonadal steroids and gonadotropins}

It is now abundantly clear that all gonadotropin-releasing machinery is in place at a very early stage in the rat and that high titers of gonadotropins are secreted very early in life. These high titers probably are the result of the immaturity of the negative gonadal steroid feedback since there seems to be an immaturity of hypothalamic receptors for gonadal steroids at this stage of development (KATO et al., I97I; Plapinger and McEwen, I973). Another factor may be the presence of binding proteins with particular affinity for estrogen (RAYNAUD et al., I97I), thus lowering the free steroid titer to vanishingly small amounts. Presumably, it is the free steroid which mediates feedback. As a consequences of the high titers of gonadotropins, plasma

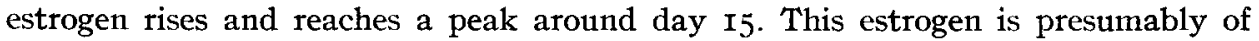
both ovarian and adrenal origin (MEIJS-RoELOFS, I973 ; WEISZ and GUNZALUS, I973 ; OJEDA et al., I975). The function of this early enhanced estrogen secretion remains to be elucidated, although it may be involved in inducing maturational changes 
in the ovary. Clearly, it does not induce appreciable growth of the uteri although ovariectomy at the day of birth is followed by a decrease in uterine weight as early as Io days following the operation (PLAGGE, I956; BAKER and KRAGT, I969). The lack of dramatic changes in uterine growth at this early phase of development indicates either that the uterus is largely unresponsive or, more probably, that the titer of biologically active unbound estradiol is very low.

After day $I_{5}$, titers of gonadotropins and estrogen decline more or less in parallel and the question arises, why? One possibility is that higher titers of progesterone at this stage act together with estrogen to suppress gonadotropin secretion (MEIJS-RoEIOFS et al., r975). Other possibilities are loss of the high affinity binding protein which would elevate free estradiol and thereby suppress gonadotropins by augmented negative feedback and, lastly, that the sensitivity of the negative feedback increases at this stage (OJEDA and RAMIREz, I973; OJEDA et al., I975). Lastly, the decline in estrogen titers may be in part related to the switch of steroid production from the interstitial ovarian tissue to the maturing follicles, an event that presumably takes place around day I5-2I. (PEDERSEN, I970; WEIsz and FERIN, I970). Before this age $\Delta^{5}, 3 \beta$-ol dehydrogenase activity is not found in granulosa cells, whereas it is present in the interstitial tissue as early as day 7 .

From day 20 until puberty, the ovary is not inactive. Mediumsized and even a few large-sized follicles are present and ovulation can be induced (MEIJS-RozLOFS et al., I973). Then just prior to puberty, a group of follicles matures, estrogen secretion is clearly enhanced as indicated by increased uterine weight, and the preovulatory discharge of gonadotropins occurs, which is followed by ovulation (OJEDA, WhEATON, JAMESON and McCANN, unpublished data). Vaginal opening occurs either just before or shortly thereafter as a result of the direct action of the estrogen secreted by the pre-ovulatory follicles. It appears that once estrogen titers have reached the critical value, positive feedback is triggered which then brings about the pre-ovulatory discharge of gonadotropins.

The question which remains to be answered is why does this take place at a particular time. Is this simply the time required for the ovary to secrete sufficient estrogen to trigger positive feedback with constant low FSH and LH stimulation, or is there a subtle decrease in negative feedback such that gonadotropins rise slightly to trigger the pre-ovulatory growth of the follicle and estrogen secretion? Finally, is there some subtle change in positive feedback which makes it possible for the hypothalamic-pituitary axis to respond to a lower titer of estradiol than required earlier with a pre-ovulatory gonadotropin discharge.

Another puzzling question is the linkage of this mechanism with the attainment of the so-called critical weight. It is quite clear that puberty is more closely related to the attainment of the critical weight than to the chronological age of the animal (FRISCH, I974). Is there some signal, perhaps mediated by the size of fat stores, which alters hypothalamic responsiveness when the critical weight has been achieved?

This is about as far as we can go towards explaining puberty in the female. We know even less in the male because it is difficult to define precisely the time of attainment of puberty in males. The hypothesis of decreasing sensitivity of negative androgen feedback still has much to recommend it in the male rat, but gonadotropin levels rise only slightly, if at all, around the time of puberty in the 
male rat. An alternate hypothesis, recently stressed by ODELI and SWERDLOFF (1974) postulates that the early FSH secretion increases responsiveness of the testes to $\mathrm{LH}$ which brings about testosterone secretion and the attainment of puberty. Perhaps, in the male, puberty is the result of both of these factors plus the increased end organ responsiveness which appears to be synchronous with the onset of puberty.

\section{Comparison of the ontogeny of gonadotropin secretion in primates and rats}

Obviously, we are particularly interested in the mechanism underlying puberty in primates and particularly in man. Recent availability of radioimmunoassays has made it possible for our knowledge of developmental processes in the primate to expand dramatically. The sequence of development in the human is remarkably similar to that in the rat with elevated levels of $\mathrm{FSH}$ and $\mathrm{LH}$ at a very early stage of development (GRUMBACH et al., I974). The major difference between man and the rat is that these high levels which appear after birth in the rat appear during fetal development in the human. This is probably related to the relative immaturity of the rat at birth. The purpose and genesis of the high titers of gonadotropins in the human fetus are just as obscure in man as they are in the rat. In the human of both sexes, there appears to be a clear pubertal increase in gonadotropin titers in contrast to the situation in the rat in which there may be only a slight rise aside from the pre-ovulatory discharge which occurs in the female. Furthermore, there is evidence for a declining sensitivity to negative feedback in the human, so that the hypothesis of puberty as the result of an increased setpoint of negative feedback to gonadal steroids has great appeal in the human of both sexes (GRUMBACH et al., 1974). Additionally, in the pubertal human, sleep-related spurts of gonadotropin secretion take place (BOyAR et al., I972). These nocturnal discharges may play an important role in the development of the gonads. As gonadotropin titers rise in the human with the approach of puberty, responsiveness to LH-RH rises (GRUMBACH et al., I974). An important difference between the rat and the primate is the relatively late development of positive feedback by gonadal steroids in both Rhesus monkey (DIERSCHKE et al., I974) and the human female (GrumbacH et al., I974). This appears to develop after the first menstruation in both man and monkey. Consequently, early menstrual cycles in primates are usually anovulatory.

Sexual Maturation 3rd Workshop August 31, September 3, 1975.

\section{ACKNOWLEDDGEMENTS}

This study was supported by grants from NIH (AM 10073 and HD 0515I) and the Ford Foundation. 


\section{RÉSUMÉ}

\section{DÉVELOPPEMENT ET MATURATION \\ DU CONTRÔLE HYPOTHALAMO-HYPOPHYSAIRE DU SYSTÈME REPRODUCTEUR}

Nous disposons aujourd'hui d'un grand nombre de nouvelles données sur l'évolution des stéroïdes gonadiques, des gonadotropines et de la sensibilité au LH-RH chez le Rat et les Primates avant la puberté. Le processus de maturation est beaucoup plus compliqué qu'on ne l'avait imaginé au départ. Le mécanisme de sécrétion des gonadotropines est fonctionnel à un stade très précoce, à un moment où la rétroaction négative des stéroïdes gonadiques est peu développé. C'est ce qui entraîne, au moins en partie, l'apparition d'un niveau élevé des gonadotropines dans le plasma. Chez la Ratte le niveau élevé des gonadotropines entraîne une sécrétion abondante d'estradiol. Ensuite, le taux des gonadotropines et de stéroïdes circulants diminue. Au moment de la puberté, on observe, au moins chez l'Homme, une augmentation de la sécrétion des gonadotropines. La puberté doit résulter en partie d'une diminution de la sensibilité du système hypothalamo-hypophysaire à la rétroaction négative des stéroïdes dans les deux sexes, à la rétroaction positive des stéroïdes chez la femelle et à une augmentation de la sensibilité des gonades et des tissus périphériques aux gonadotropines circulantes.

\section{REFERENCES}

Aiver M. S., Chiappa S. A., Fink G., I974. A priming effect of luteinizing hormone releasing factor on the anterior pituitary gland in the female rat. $J$. Endocr., 62, 573-588.

BAKER F. D., KragT C. L., I 669 . Maturation of the hypothalamic-pituitary-gonadal negative feedback system. Endocrinology, 85, 522-527.

Bloch G. J., Masken J., KRagt C. L., Ganong W. F., r974. Effect of testosterone on plasma LH in male rats of various ages. Endocrinology, 94, 947-95I.

Boyar R., Finkelstein J., Roffwargh H., Kapen S., Weitzman E., Hellam L., 1972. Synchronization of augmented luteinizing hormone secretion with sleep during puberty. New Eng. $J$. Med., 287, 582-586.

Caligaris L., Astrada J. J., Taleisnik S., 1972. Influence of age on the release of luteinizing hormone induced by estrogen and progesterone in immature rats. $J$. Endocr., 55, 97-Io3.

Campbel H. J., Gallardo E., 1966. Gonadotropin-releasing activity in the median eminence at different ages. J. Physiol., 186, 689-697.

Castro-Vazguez A., McCANn S. M., I975. Cyclic variations in the increased responsiveness of the pituitary to luteinizing hormone-releasing hormone (LH-RH) induced by LH-RH. Endocrinology, 97, I3-I9.

Corbin A., Daniels E. L., I967. Changes in concentrations of female rat pituitary FSH and stalk median eminence follicle stimulating hormone releasing factor with age. Neuroendocrinology, 2, 304-3I4.

Debeljuk L., Arimura A., Schally A. V. I972a. Studies on pituitary responsiveness to LH-RH in intact male rats of different ages. Endocrinology, 90, 585-588.

Debeljuk L., Arimura A., Schally A. V., I972 b. Pituitary responsiveness to LH-RH in intact female rats of different ages. Endocrinology, 90, 1499-1502.

de Hertogh R., EKka E., VANDerheyden I., Hoet J. J., I970. Metabolic clearance rates and the interconversion factors of estrone and estradiol- $>\beta$ in the immature and adult female rat. Endocrinology, 87, 874-880.

Dierschke D. J., Karsch F. J., Weick R. F., Weiss G., Hotchiss J., Knobil E., I974. Hypothalamic-pituitary regulation of puberty in the Rhesus monkey, I04-I14, in : GRUMBACH M., GRAVE G., MAYER F., The control of the onset of puberty, Wiley and Sons, Inc., New York.

Döhler K. D., Wuttke W., 1974. Serum LH, FSH, prolactin and progesterone from birth to puberty in female and male rats. Endocrinology, 94, 1003-1008.

Donovan B. T., Van der Werfa ten Bosch J. J., I965. Physiology of puberty, I-2I6, in : Barcroft S. H., Davson H., Patton W. D., Monographs of the physiological society, London.

FRISCH R. E., 1974. Critical weight at menarche, initiation of the adolescent growth spurt, and control of puberty, 403-423, in : Grumbach M., Grave G., MaYer F., The control of the onset of puberty, Wiley and Sons, Inc., New York. 
Gelato M., Wuttke W., I975. Evidence for a positive feedback action of estrogen on LH secretion in immature female rats. IRCS Med. Sci., 3, 260-26r.

Goldman B., Grazia Y. R., Kamberi I. A., Porter J. C., I97I. Serum gonadotropin concentrations in intact and castrated neonatal rats. Endocrinology, 88, $771-776$.

Grumbach M. M., Roth J. C., Kaplan S. L., Kelch R. P., I974. Hypothalamic-pituitary regulation of puberty : Evidence and concepts derived from clinical research, I 5 -I 66, in : GRUMBACH M., GRAVE G., MAYER F., The control of the onset of puberty, Wiley and Sons, Inc., New York.

Hooker C. W., 1942. Pubertal increase in responsiveness to androgen in the male rat. Endocrinology, 30, $77-84$.

Kato T., Atsumi Y., Inaba M., 197r. Development of estrogen receptors in the rat hypothalamus. J. Biochem. (Jap.), 70, 1051-1053.

Kragt C. L., Dahlgren J., 1972. Development of neural regulation of follicle stimulating hormone (FSH) secretion. Neuroendocrinology, 8, 30-40.

McCann S. M., OJeda S. R., Negro-Vilar A., 1974. Sex steroid, pituitary and hypothalamic hormones during puberty in experimental animals, I-I9, in : GRUMbaCH M., GRAVE G., MAYER F., The control of the onset of puberty, Wiley and Sons, Inc., New York.

Meijs-Roelofs H. M. A., I973. Sexual maturation in the female rat. Thesis Erasmus University, Rotterdam.

Meijs-Roelofs H. M. A., Uilenbroek J. TH. J., de Jong F. H., Welschen R., 1973 b. Plasma oestradiol-I $\beta$ and its relationship to serum follicle-stimulating hormone in immature female rats. $J$. Endocr., 59, 295-310.

Meijs-Roelofs H. M. A., Uilenbroek J. TH. J., Osman P., Welschen R., r973a. Serum levels of gonadotropins and follicular growth in prepubertal rats, 3-II, in : PETERs H., The development and maturation of the ovary and its function, Excerpta Medica, Amsterdam.

Meijs-Roelofs H. M. A., de Greef W. J., Uilenbroek J. TH. J., I975. Plasma progesterone and its relationship to serum gonadotrophins in immature female rats. J. Endocr., 64, 329-336.

Mryachi Y., Nieschlag E., LipsetT M. B., r973. The secretion of gonadotropins and testosterone by the neonatal male rat. Endocrinology, 92, I-5.

Negro-Vilar A., KrUlich L., McCANN S. M., I973a. Changes in serum prolactin and gonadotropins during sexual development of the male rat. Endocrinology, 93, 660-664.

Negro-Vilar A., OJEda S. R., McCann S. M., I973 $b$. Evidence for changes in sensitivity to testosterone negative feedback and gonadotropin release during sexual development in the male rat. Endocrinology, 98, 729-735.

OdELL W. D., SWERdLOFF R. S., I974. The role of the gonads in sexual maturation, 313-332, in : Grumbach M., Grave G., Mayer F., The control of the onset of puberty, Wiley and Sons, Inc., New York.

OJeDA S. R., RAmirez V.D., r972. Plasma level of LH and FSH in maturing rats : Response to hemigonadectomy. Endocrinology, 90, 466-472.

OJEDA S. R., RAMIREZ V. D., I973. Short-term steroid treatment on plasma LH and FSH in castrated rats from birth to puberty. Neuroendocrinology, 13, I00-1 I4.

OJEDA S. R., McCanN S. M., I974. Development of dopaminergic and estrogenic control of prolactin release in the female rat. Endocrinology, 95, I499-1505.

OJEDA S. R., KalRa P. S., McCANN S. M., 1975. Further studies on the maturation of the estrogen negative feedback on gonadotropin release in the female rat. Neuroendocrinology (in press).

OJEDA S. R., I976. Maturation of the control of gonadotropin and prolactin release in the rat. Ann. Biol. anim. Bioch. Biophys., 16,

Pedersen T., I97o. Kinetics of follicle growth in the ovary of the immature mouse, 223-225, in : Butr W. R., CRooke A. C., RylE M., Gonadotropins and ovarian development, E. and S. Livingstone, London.

Pfeiffer C. A., 1936. Sexual differences of the hypophyses and their determination by the gonads Am. J. Anat., 58, 195-225.

Plagge J. C., I956. Effect of prepubertal castration on body and thymus weight in the immature albino rat. Anat. Rec., 124, Ior-I Io.

Plapinger L., McEwen B. S., I973. Ontogeny of estradiol-binding sites in rat brain. I. Appearance of presumptive adult receptors in cytosol and nuclei. Endocrinology, 93, III9-II28.

PRICE D., ORTIz E., I944. The relation of age to reactivity in the reproductive system of the rat. Endocrinology, 34, 2I5-239.

Ramirez V. D., McCanN S. M., 1963. Comparison of the regulation of LH secretion in immature and adult rats. Endocrinology, 72, 452-464.

Ramirez V. D., McCanN S. M., I965. Inhibitory effect of testosterone on luteinizing hormone secretion in immature and adult rats. Endocrinology, 76, 412-417.

Ramirez V. D., SAwYer C. H., I966. Changes in hypothalamic luteinizing hormone releasing factor in the female rat during puberty. Endocrinology, 78, 958-964.

Ramirez V. D., 1974. Endocrinology of puberty, I-28, in : GreeP R. O., Astwood F. B., Handbook of physiology, Williams and Wilkins, Baltimore. 
Raynaud J. P., Mercier-Bodard C., Baulieu E. E., 1971. Rat estradiol binding plasma protein (EBP). Steroids, 18, 767-788.

Resko J. A., FEDER H. H., GoY R. W., 1968. Androgen concentrations in plasma and testes of developing rats. $J$. Endocr., 40, 485-49I.

Root A. W., Shapiro B. H., Duckett G. E., Goldman A. S., I975. Effect of synthetic LH-RH in newborn rats. Proc. Soc. Exptl. Biol. Med., 148, 631-633.

Smith E. R., Davidson J. M., I968. Role of estrogen in cerebral control of puberty in female rats. Endocrinology, 82, 100-108.

Swerdloff R. S., Walsch P. C., Jacobs H. S., Odele W. D., I97x. Serum LH and FSH during sexual maturation in the male rat : Effect of castration and cryptorchidism. Endocrinology, 88, 120-128.

Voogt J. L., Chen C. L., Meites J., 1970. Serum and pituitary prolactin levels before, during and after puberty in female rats. Am. J. Physiol., 218, 396-399.

Watanabe S., McCann S. M., 1969. Alterations in pituitary FSH and FSH-RF during puberty. Proc. Soc. Exptl. Biol. Med., 132, 195-201.

WeIsz J., FERIN M., r97o. Pituitary gonadotropins and circulating LH in immature rats : A comparison between normal females and males and females treated with testosterone in neonatal life, 339-50, in : Butr W. R., Crooke A. C., Ryle M., Gonadotropins and ovarian development, E. and S. Livingstone, London

Weisz J., Gunsalus P., I973. Estrogen levels in immature female rats : true or spurious-ovarian or adrenal? Endocrinology, 93, 1057-1065. 